\title{
Pathogenecity of Pseudomonas anguilliseptica Infection in Goldfish (Cyprinus Carpio)
}

\author{
AjengAekanurmaningdyah ${ }^{1}$ and Kurniasih ${ }^{2 *}$ \\ ${ }^{1}$ Clinical Department, Brawijaya University, Indonesia
}

${ }^{2}$ Pathology Department, Gadjah Mada University, Indonesia

Submission: July 10, 2018; Published: July 19, 2018

*Corresponding author: Kurniasih, Clinical Department, Faculty of Veterinary Medicine, Brawijaya University, Indonesia,

Email: kurniasih_1951@yahoo.co.id

\begin{abstract}
Pseudomonas anguilliseptica caused Red Spot Disease (Sekitten - Byo) resulted a very high mortality in fishes and serious economic losses as a Quarantine Fish and Diseases group I.Aim of study is to identify Ps. anguilliseptica with conventional, molecular, and the histopathological changes. Local isolate of Ps. anguilliseptica were identified by morphological and molecular tests. Molecular identification in $16 \mathrm{~S}$ rRNA fragment used forward primer Psan-F (21-mer:5'- TTGGGAGGAAGGGCA-GTAACC-3') and reverse Psan-R(20-mer: 5' - TGCGCCACTAAAATCTCAAG-3'), and sequencing. Pathogenicity test used 18 fishes divided into 2 groups each groupconsist of 9 fishes. Group I, fish was infected intramuscularly with buffer saline as a control and group II, fish was infected intramuscularly with $0.1 \mathrm{ml}$ LC-50 of Ps. anguilliseptica suspension. Fishes were autopsied on $1^{\text {st }}$ day, $8^{\text {th }}$ day and $15^{\text {th }}$ day after infection. The morphological resultsshowed the colonies appear round, grayish, convex, entire, diameter about $1 \mathrm{~mm}$ with rod-shaped cells and Gram negative. Biochemical results showed a positive reaction to oxidase, catalase, motility, gelatinase, $\mathrm{pH} 5.3$ to 9.7 and sucrose; and negative reactions to indole, glucose and lactose. Alignment sequences of local isolate of Ps. anguilliseptica showed the similarities with the Ps.anguillisepticaof Gene Bank 94\%. Histopathological result was myositis and congestion of brain at the $1^{\text {st }}$ day. At the 8 th day showed necrosis and myositis,renal necrosis, enteritis hemorrhagica, epicarditis, and congestion of brain. At the $15^{\text {th }}$ day muscle necrosis, epidermatitis, hepatitis, splenitis, epicarditis, enteritis hemorrhagica, and congestion of brain.
\end{abstract}

Keywords: Pseudomonas anguilliseptica; Commoncarp (Cyprinus carpio); Pathogenicity;Molecular

\section{Introduction}

Pseudomonas anguilliseptica was firstly identified in 1972 as the cause of Red Spot Disease or "Sekiten- byo"at aquaculture of Anguilla japonica in Japan [1]. Pseudomonas anguilliseptica was also the etiology of "Winter Disease Syndrome"[2-5].The disease could attack Anguilla japonica, Anguilla anguilla, Lates calcalifer, Plecoglossus altivelis, Carrassius auratus, Oreochromis niloticus, Pangasiusspp, and Cyprinus carpio. Distribution of PS. Anguilliseptica infection was Japan, Taiwan, Malaysia, Europe, until Indonesia including Yogyakarta, Bali, Nabire, Nangroe Aceh Darussalam, West Kalimantan and South Sumatera[6].Symptoms of disease were ascites, petechiae hemorrhage, darker skin, exophthalmia, and loosing scale. Liver was pale, hemorrhage of kidney, congestion of intestine and fibrinous exudates[4,7].

The Japanese eel (Anguillajaponica) showed petechial hemorrhage on the skin, especially at the bottom jaw, operculum, ventral and pectoral fins. The mortality at the second days, fish showed congestion of peritoneum and liver, swollen and black colour ofkidney and spleen[8]. Pseudomonas anguillisepti cacould be isolated from spleen, kidney, liver, eye. Intestine, fin, lesion of dermis, and ascites $[3,9,10]$. Pseudomonas anguilliseptica was also found in the blood [2]. Romalde etal.[11] has identified Ps. Anguilliseptica based on PCR in 16S rRNA region using internal organ.The amplification product was 418 base pair.A pair of primers used was forward Psan-F (21-mer;5'-TTGGGAGGAAGGGCA- GTAACC-3') and reverse Psan-R (20-mer; 5'-TGCGCCACTAAAATCT CAAG- 3'). Pathogenecity research of Ps. Anguilliseptica has been experimentally done by intramuscular injection [12], intraperitoneally, and subcutaneous injection[2]. The aim of study to find out the pathogenecity of Ps.anguilliseptica from local isolates experimentally infection in gold fish(Cyprinuscarpio).

\section{Methods}

\section{Re- identification of Ps. anguilliseptica}

The isolate of Ps.anguilliseptica collected from gouramy fish in Yogyakarta was identified based on Austin \&Austin[13], it can be seen in Table 1. 
Table 1: Morphological identification of Ps. anguilliseptica.

\begin{tabular}{|c|c|c|}
\hline & Local Isolate & $\begin{array}{c}\text { Ps.anguilliseptica } \\
\text { (Austin\&Austin, 2007) }\end{array}$ \\
\hline Oxidase & + & + \\
\hline Katalase & + & + \\
\hline Motilitity & + & - \\
\hline Indole & - & - \\
\hline H2S & - & + \\
\hline Gelatinase & + & + \\
\hline pH 5.3-9.7 & + & - \\
\hline Glucose & - & - \\
\hline Lactose & - & + \\
\hline Sucrose & + & + \\
\hline
\end{tabular}

\section{Molecular analysis}

Local isolate was extracted using RNA extraction kit (DNeasy®Qiagen). Gen amplification of 16SrRNA used primer forward Psan-F (21-mer;5'-TTGGGAGGAAGGGCA-GTAACC- 3') andreverse primer Psan-R(20-mer;5'- TGCGCCACTAAAATCTCAAG-3'). The PCR was performed in a total reaction volume $25 \mu \mathrm{L}$ containing $12 \mu \mathrm{L}$ master mix (GoTaq Green), $1 \mu \mathrm{L}$ of each primer (10pMol), $9 \mu \mathrm{L}$ of Nuclease free water and $2 \mu \mathrm{L}$ DNA template. The mixture was incubated in a automatic thermal cycler programmed for 35 cycles, 1 cycles of pre denaturation $95^{\circ} \mathrm{C}$ for 3 minutes, denaturation $95^{\circ} \mathrm{C}$ for $20 \mathrm{~s}$, annealing $63^{\circ} \mathrm{C}$ for 20 seconds, extension $72^{\circ} \mathrm{C}$ for $30 \mathrm{~s}$ and final extension $72^{\circ} \mathrm{C}$ for 5 minutes [11]. The amplification product was electrophoresed in $1 \%$ of agarose gel in buffer TAE, 100 voltages for 45 minutes. Amplification product was then purified and sequenced.

\section{Experimentally infection of Ps. Anguilliseptica in gold fish}

Number of 18 gold fish was divided into two groups. Group one was injected intramuscularly with $0,1 \mathrm{~mL}$ of solution containing Ps. Anguilliseptica 5,75 x $10^{6} \mathrm{cell} / \mathrm{mL}$, the second group was injected intramuscularly with $0.1 \mathrm{~mL}$ of $\mathrm{NaCl}$ fisiologis solution as a control. Two groups were observed for 15 days, they were autopsied at the first, the eight, and the fifteenth day after injection.They were also processed for histopathological examination.

\section{Result}

Result of amplification of Ps. Anguilliseptica showed 500-750bp (Figure 1), that it was different from previous report at 418bp [11]. Sequencing result of gen16SrRNAof Ps. Anguilliseptica from Yogyakarta has been compared to Ps. Anguillisepticaof Gene Bank (FJ608122.1), it was found that the nucleotide length of local isolate of Ps. Anguilliseptica was 546bp (Figure 1). Alignment result showed that the similarity of Ps.anguilliseptica sequences from local isolate and Ps. Anguillisepticafrom GeneBank was 94\% (Figure 2).

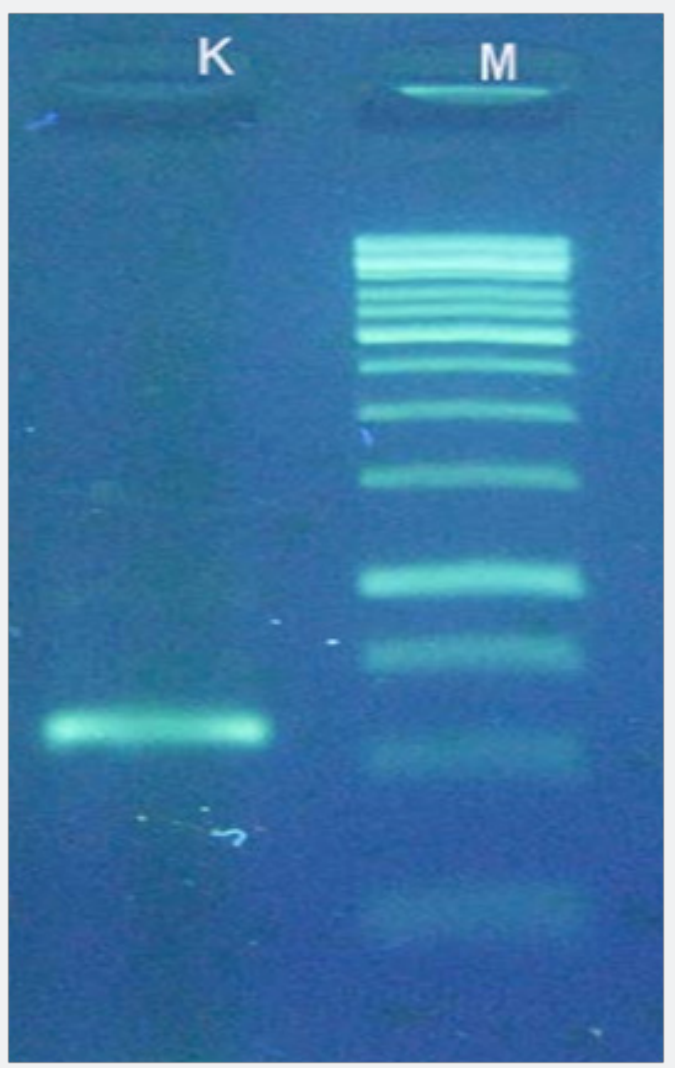

Figure 1: Amplification of $16 \mathrm{~S} r R N A$ fragment. $\mathrm{K}$ was isolate of $P s$. Anguilliseptica from Yogyakarta, M was $1 \mathrm{~Kb}$ marker. 


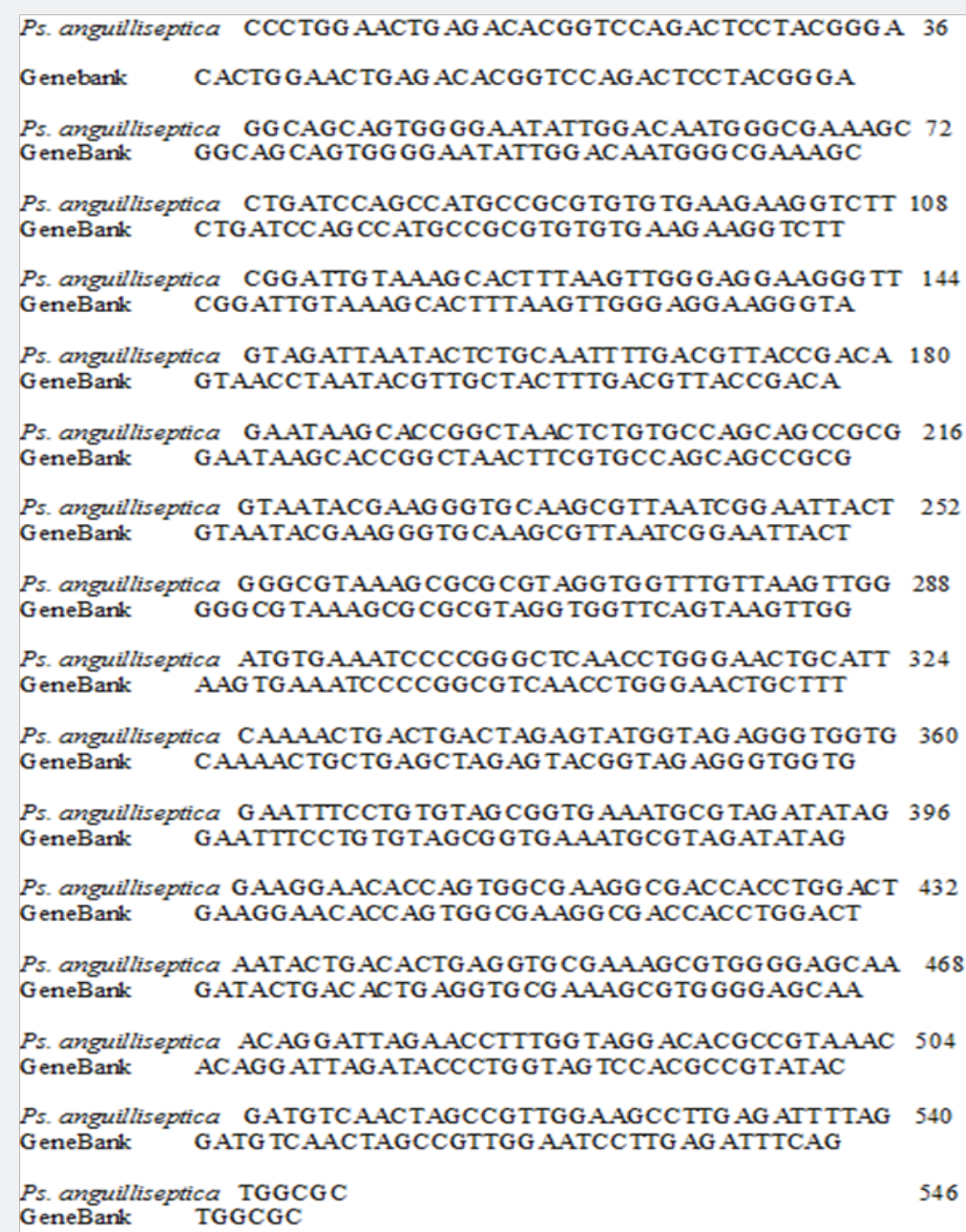

Figure 2: The Alignment result of $P$ s.anguilliseptica sequences from local isolatewas compared to sequences from Gene Bank(FJ608122.1).

\section{Clinical symptom}

Gold fish that were infected with Ps.anguilliseptica showed several symptoms such as anorexia, stay at the bottom of aquarium, slow swimming, ascites, loosing scale, and lesion of skin(Table 2).

Table 2: Clinical symptoms of gold fish that was infected with Ps. anguilliseptica.

\begin{tabular}{|c|c|c|c|}
\hline Symptoms & Day-1 & Day-8 & Day-15 \\
\hline Anorexia & + & + & + \\
\hline $\begin{array}{c}\text { Stay at the } \\
\text { bottom }\end{array}$ & + & + & + \\
\hline $\begin{array}{c}\text { Slow } \\
\text { swimming }\end{array}$ & + & + & + \\
\hline Slow reaction & + & + & + \\
\hline Ascites & - & + & + \\
\hline Broken fin & - & + & + \\
\hline Loosing scale & - & + & + \\
\hline Lesion of skin & - & + \\
\hline
\end{tabular}

\section{Pathogenecity}

The histopathological organs such as skin, liver, cor, kidney, spleen, intestine, and brain of control group were no changes (Figure 3). At the first day of infection the fish showed myositis, and congestion of brain. At the eight day of infection, fish was suffered from myositis, necrosis of kidney, enteritis, epicarditis, and congestion of brain (Figure 4). At the fifteenth day, fish showed necrosis of muscle, dermatitis, hepatitis, splenitis, enteritis, epicarditis, and congestion of brain (Figure $5 \& 6$ ). The histopathological changes were varied from days one, eight, and fifteen.Lesion of skin was first congestion and myositis at the first day, it became necrosis at day fifteen. Congestion and inflammation could be occurred because of the presence of intracellular enzyme with hemolytic and proteolytic activity that irritated the skin [14]. Necrosis of muscle has been reported by Gallardo et al.[15] in Gilhead Sea Bream (S. aurata) with winter syndrome or Ps.anguilliseptica infection. Congestion and necrosis in liver, kidney, and other organs were also reported by Ellis et al.[16,17]. Necrosis of kidney especially in glomerulus could be caused by toxin from Ps. Anguilliseptica[18]. 


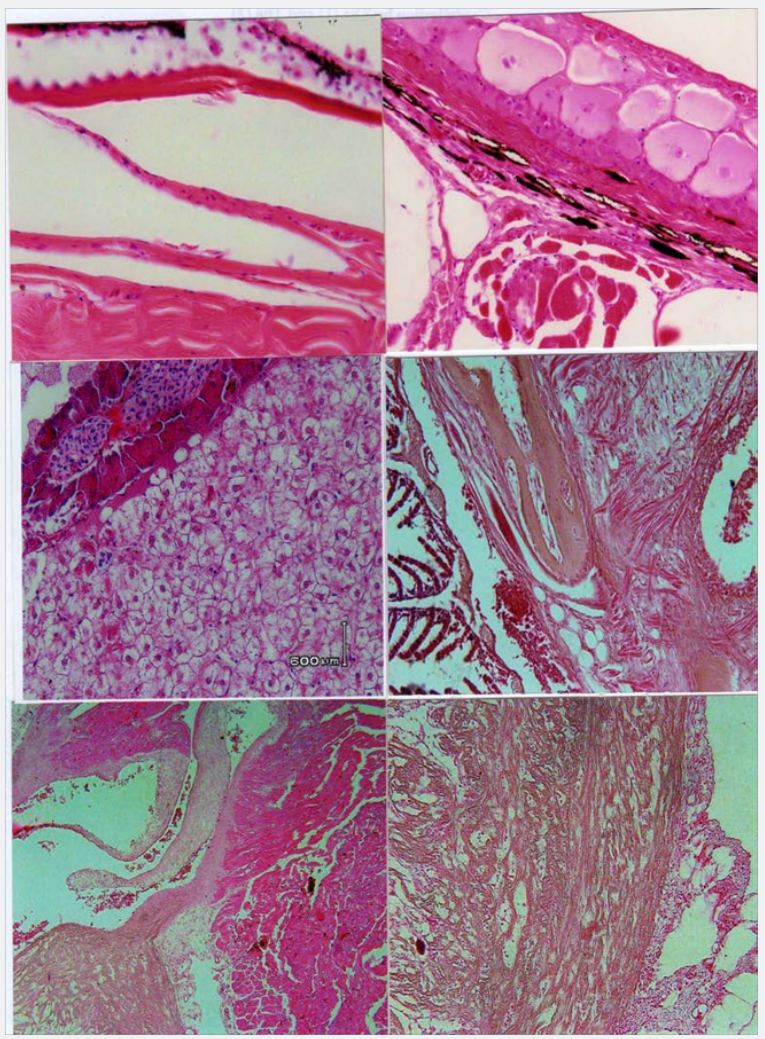

Figure 3: Histology of normal organ of gold fish in control group, A skin;B kidney; Chepar; D gill; E cardiac valve; $F$ intestine. Scale bar $50 \mu \mathrm{m}$.

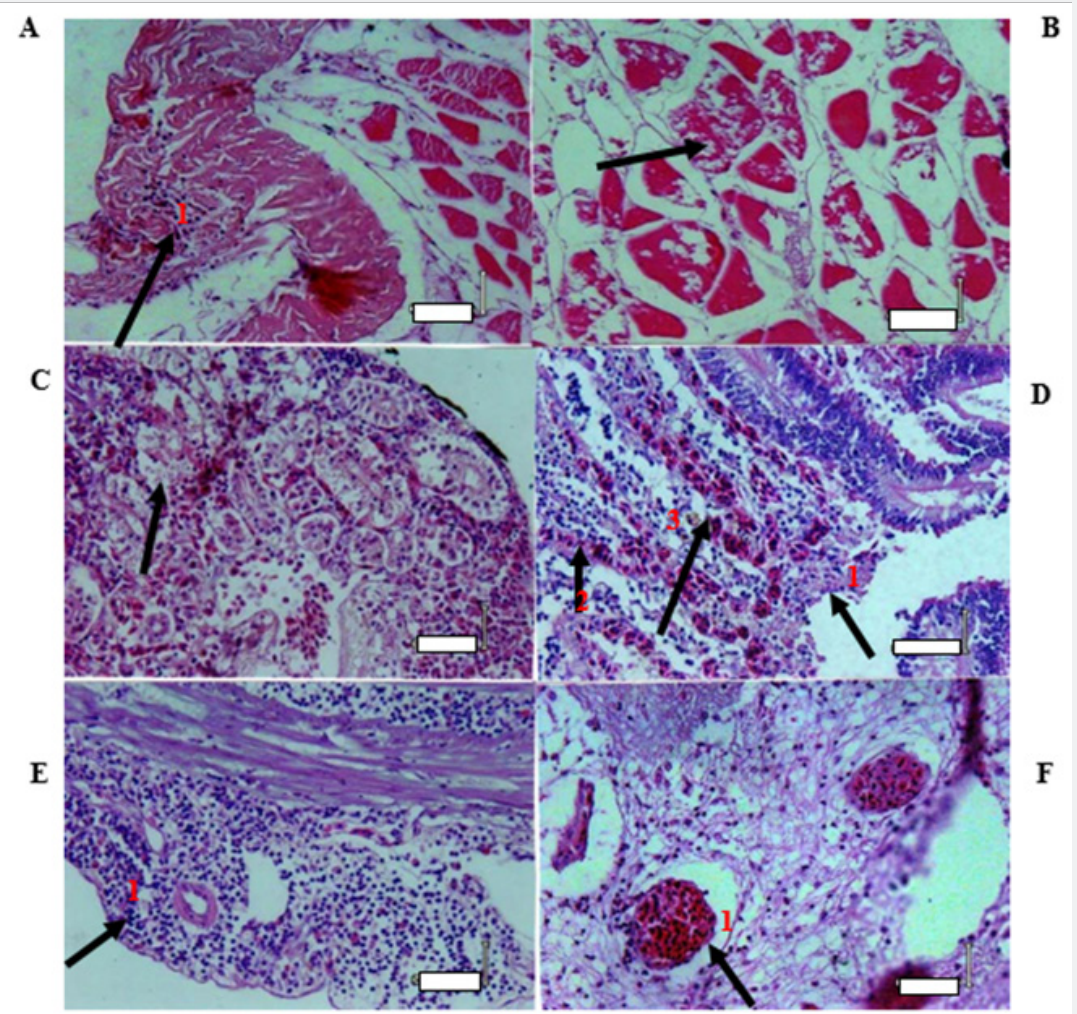

Figure 4: Histopathology of gold fish organs at the eight day of infection with Ps. AnguillisepticaMyositis (A); Necrosis of muscle (B); Necrosis of tubulus kidney (C); Erosion (1), Inflammation (2) and hemorrhage (3) of intestine (D); Epicarditis (E); Congestion of brain (F). Scalebar $50 \mu \mathrm{m}$. 


\section{International Journal of Cell Science \& Molecular Biology}
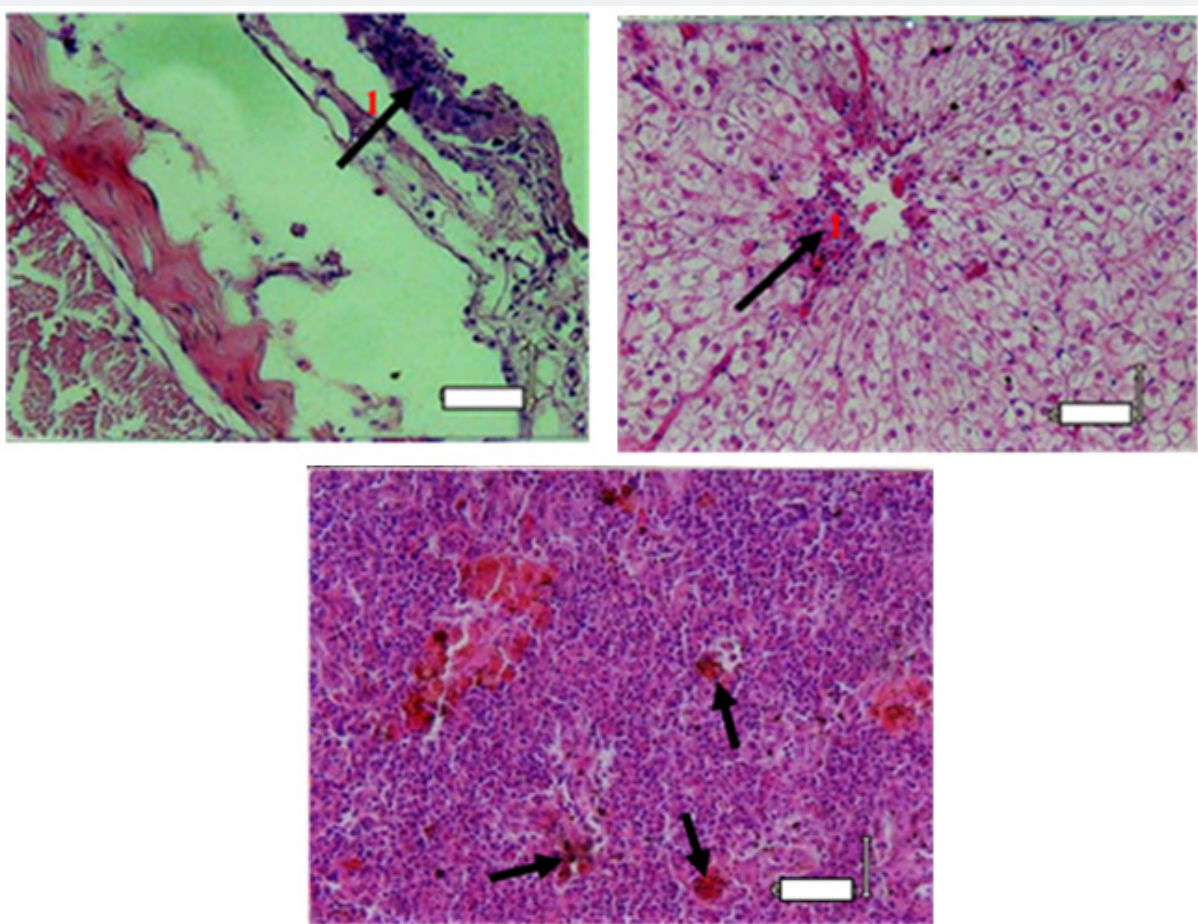

Figure 5: Histopathology of gold fish at the fifteenth day of infection. Necrosis of muscle(A); Epidermatitis (B); Congestion and hepatitis (C); Splenitis. Scalebar50um.

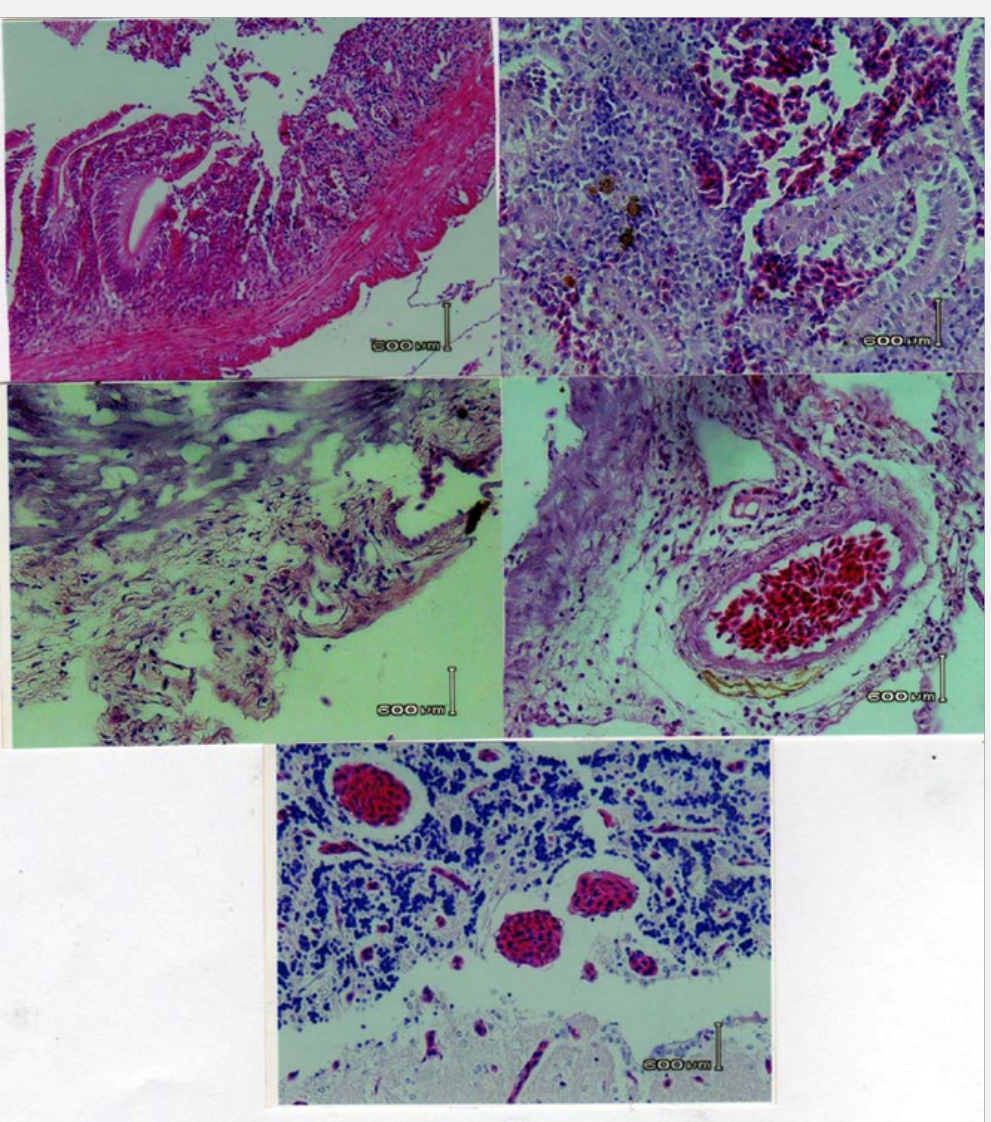

Figure 6: Histopathology of gold fish at the fifteenth day of infection. Enteritis hemorrhagica (A); congestion and epicarditis (B); congestion of brain (C). Scalebar $50 \mu \mathrm{m}$. 
The heart was normal at the first day, it showed inflammation at the eight day of infection, and all fish became epicarditis. The inflammation of intestine and spleen was already found at the first day, it became increase at the eight day, and it was decrease at the day 15 . The result was the same as Hossain and Chowdhury research in 2009, the increase number of melanomakrofag that brownish colour became a patognomonic changes in spleen and kidneyafter Ps.anguilliseptica infection [5]. Bacteremia of Ps. Anguilliseptica consisted of three phases, the first phase was 90-99\% of bacteria gone from circulation and would be back into circulation depend on individua and environment. The second phase, bacteria was found in the circulation with a low concentration or grow slowly, then gone because of liver and spleen activities. At the third phase, Ps. Anguilliseptica caused fatal infection after the number of bacteria was highly increase again in the blood vessel until the fish died [12].

\section{Conclusion}

Local isolate of Ps.anguilliseptica was similar to Ps.anguilliseptica from gene bank based on molecular study in 16SrRNA gen. Pathogenecity of Ps.anguilliseptica infection was occurred bacteremia, congestion, and necrosis in several organ such as skin and brain at the first day. It became necrosis and inflammation at the eight day, and histopathological changes were found in all internal organ at the fifteenth day of infection.

\section{References}

1. Wakabayashi H, Egusa S (1972) Characteristics of A Pseudomonas sp. From an Epizootic of Pond-Cultured Eels (Anguilla japonica). Bulletin Japan Society Scientific Fish 38: 577-587.

2. Berthe FCJ, Michel CM, Bernardet JF (1995) Identification of Pseudomonas anguilliseptica Isolated from Several Fish Species in France. Disease of Aquati Organisms 21: 151-155.

3. Domenech A, Garayzabar JFF, Lawson P, Garcia JA, Cutuli MT, et al. (1997) Winter Disease Outbreak in Sea Bream (Sparus aurata) Associated with Pseudomonas anguilliseptica Infection. Aquaculture156: 317-326.

4. Blanco MM, Gibello A, Vela AI, Moreno AA, Dominiguez, etal. (2002) PCR Detection and PGFEDNA Macrorestriction Analyses of Clinical Isolates of Pseudomonas anguilliseptica From Winter Disease Outbreaks in Sea Bream Sparus aurata. Dis Aquat Organ 50: 19-27.
5. Magi GE, Lopez RS, Magarinos B, Lamas J, Romalde JL (2009) Experimental Pseudomonas anguilliseptica Infection in Turbot Psetta maxima (L): A Histopathological and Immunohistochemical Study. Eur J Histochem 53(2): 73-79.

6. Anonim (2010) Surat Keputusan Menteri Kelautan dan Perikanan RepublikIndonesia.

7. Eissa NME, El-Ghiet ENA, Shaheen AA, Abbas A (2010) Characterization of Pseudomonas Spesies Isolated from Tilapia "Oreochromis niloticus" in Qaraoun and Wadi-El-Rayan Lakes, Egypt. Global Veterinarian 5(2): 116-121.

8. Haenen OLM, Davidse A (2001) First Isolation and Pathogenicity Studies with Pseudomonas anguilliseptica from Disease European eel Anguilla anguilla $(L)$ in the Netherlands Aquaculture 196: 27-36.

9. Wiklund T, Bylund G (1990) Pseudomonas anguilliseptica as a Pathogen of Salmonid Fish in Finland. Disease of Aquatic Organism 8: 13-19.

10. Lonnstrom L, Wiklund T, Bylund G (1994) Pseudomonas anguilliseptica Isolated from Baltic Herring Clupeaharengus membras With Eye Lesion. Disease of Aquatic Organisms 18: 143-147.

11. Romalde JL, Romalde SL, Ravelo C, Magarinos B, Toranzo AE (2004) Development and Validation of A PCR-Based Protocol for The Detection of Pseudomonas anguilliseptica. Fish Pathology 39(1): 33-41.

12. Nakai T, Kanemori Y, Nakajima K, Muroga K (1985) The Fate Pseudomonas anguilliseptica In Artificially Infected Eels Anguilla japonica. Fish Pathology19(4): 253-258.

13. Austin B, Austin DA (2007) Bacterial Fish Pathogens. Disease of Farmed and Wild Fish, ( $4^{\text {th }}$ edn), Springer -Praxis, Goldaming, England.

14. Sakr SFM, El-Rhman AMM (2008) Contribution on Pseudomonas septicaemia Caused by Pseudomonas anguilliseptica in Cultured Oreochromis niloticus. Procedings $8^{\text {th }}$ International Symposium in Tilapia Aquaculture.

15. Gallardo MA, Rabanal MS, Ibars A, Padros F, Blasco J, et al. (2003) Functional Alterations Associated With "Winter Syndrome" in Gilthead Sea Bream (Sparus aurata). Aquaculture 223: 15-27.

16. Ellis AE, Dear G, Stewart DJ (1983) Histopathology of "Sekiten-byo" by Pseudomonas anguilliseptica in The European eel, Anguilla anguilla L., in Scotland. Journal of Fish Disease 6: 77-79.

17. Rahman H (2006) Efektifitas Berbagai Antibiotik Terhadap Bakteri Pseudomonas anguilliseptica Pada Ikan Mas (Cyprinus carpio). Thesis Sekolah Pascasarjana, Universitas Gadjah Mada, Yogyakarta, Indonesia.

18. Hossain MM, Chowdhury BR (2009) Pseudomonas anguillisepticaas A Pathogen of Tilapia (Oreochromis niloticus) Culture in Bangladesh. Bangladesh Research Publications Journal 2(4): 712-721.

\section{Your next submission with Juniper Publishers will reach you the below assets}

- Quality Editorial service

- Swift Peer Review

- Reprints availability

- E-prints Service

- Manuscript Podcast for convenient understanding

- Global attainment for your research

- Manuscript accessibility in different formats ( Pdf, E-pub, Full Text, Audio)

- Unceasing customer service

Track the below URL for one-step submission https://juniperpublishers.com/online-submission.php 